Geomorphology

Elsevier Editorial System(tm) for

Manuscript Draft

Manuscript Number:

Title: Geomorphological consequences of glacier advance across a paraglacial rock avalanche deposit

Article Type: Research Paper

Keywords: glacial geomorphology; moraine; paraglacial; reworking; rock avalanche; sedimentology.

Corresponding Author: Dr. Simon Cook,

Corresponding Author's Institution: Manchester Metropolitan University

First Author: Simon Cook

Order of Authors: Simon Cook; Philip R Porter; Charles A Bendall

Abstract: Glacial reworking of paraglacial rock slope material has been inferred from long-deglaciated terrains to be an important component of glacial sediment transfer. We provide the first description from a contemporary glacial environment of the geomorphological consequences of glacier advance (of the Feegletscher Nord, Switzerland) across a

paraglacial rock avalanche deposit. The landform-sediment assemblage at Feegletscher includes a rock avalanche scar, pulverised bedrock on the opposite valley wall, a down-valley tongue of unaltered rock avalanche debris, and a small arcuate end moraine that encloses a zone of hummocky debris. The sedimentology of the end moraine and hummocky material is conditioned by rock avalanche debris and can be differentiated from glacial materials that have no component of rock avalanche debris, indicating that the contribution of glacially reworked rock avalanche debris may be recognisable in deglaciated terrain. Remarkably, much of the overridden rock avalanche debris that underlies the surface hummocky sediments has maintained its angularity and delicate brecciation

features, despite glacial action of up to 40 years duration. Previous studies assumed that debris transport would be enhanced significantly during the initial stages of glacier advance across rock avalanche debris, but we suggest that the large openwork blocks that characterise the surface of such deposits limits the potential for glacial reworking because of its high shear strength and ability to transmit subglacial meltwater efficiently.

Suggested Reviewers: Sven Lukas

Senior Lecturer in Physical Geography, School of Geography, Queen Mary, University of London

s.lukas@qmul.ac.uk

Dr Sven Lukas is a world expert in paraglacial and glacial systems. He has significant experience in glacial sedimentology and geomorphology. 


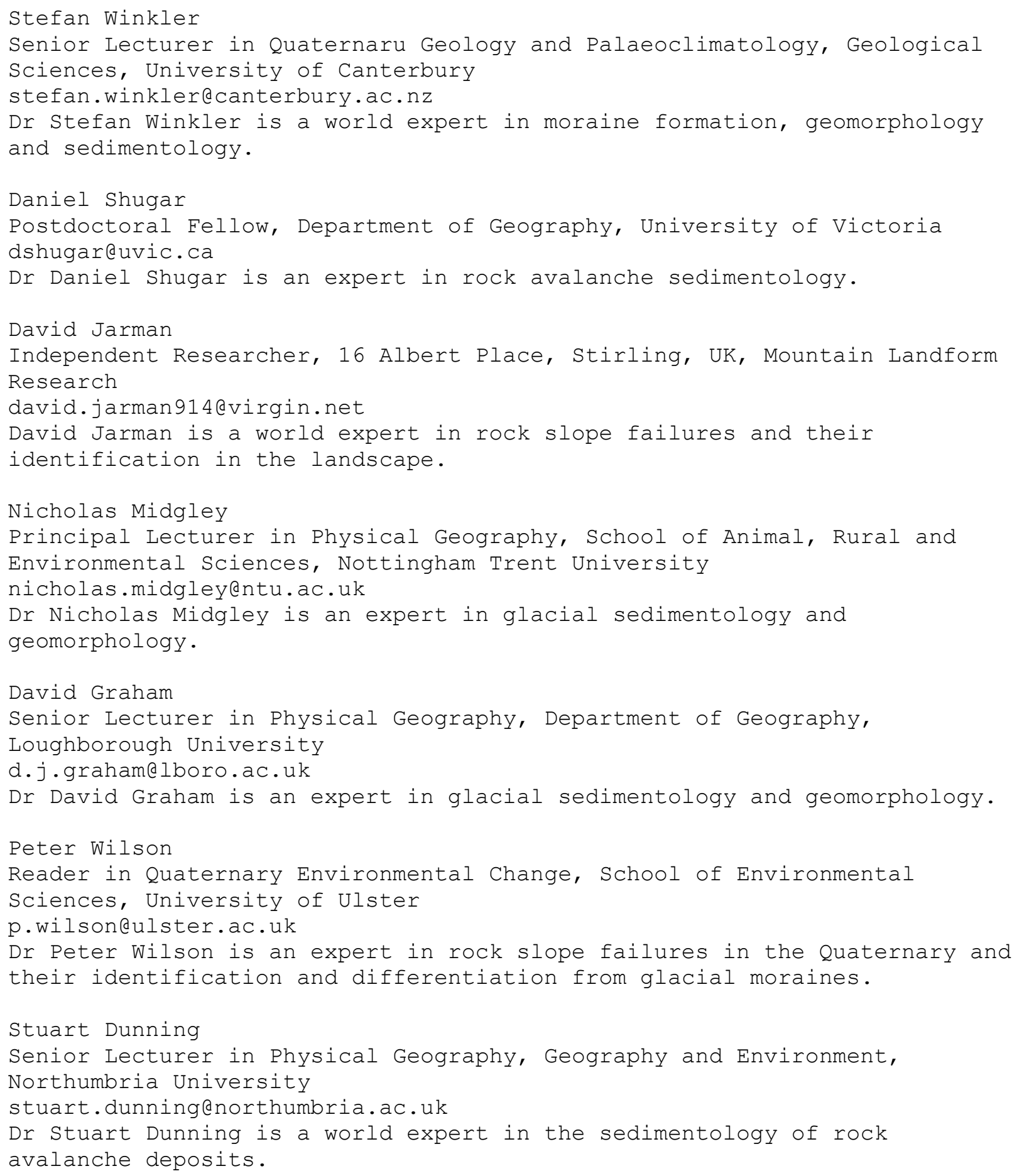


Highlights (for review)

- We describe geomorphology produced by glacier advance across rock avalanche debris.

- Glacially reworked rock avalanche material is distinct from other glacial deposits.

- Glacially overridden rock avalanche debris experienced very little reworking.

- Openwork blocky rock avalanche sedimentology reduces its erodibility by glaciers.

- Enhanced glacial sediment transfer involving paraglacial material is not certain. 


\section{Geomorphological consequences of glacier advance across a 2 paraglacial rock avalanche deposit}

3

4 Simon J. Cook ${ }^{1^{*}}$, Philip R. Porter ${ }^{2}$, Charles A. Bendall ${ }^{3}$

$5{ }^{1}$ School of Science and the Environment, Manchester Metropolitan University, Chester Street, 6 Manchester, M1 5GD, UK.

$7 \quad{ }^{2}$ Division of Geography and Environmental Science, School of Life Sciences, University of

8 Hertfordshire, Hatfield, AL10 9AB, UK.

$9{ }^{3}$ Institute of Geography and Earth Sciences, Aberystwyth University, Ceredigion, SY23 3DB, UK. 10

*Corresponding author (‥J.Cook@mmu.ac.uk or basalice@gmail.com; +44[0]161 2471202)

\section{Abstract}

Glacial reworking of paraglacial rock slope material has been inferred from long-deglaciated terrains to be an important component of glacial sediment transfer. We provide the first description from a contemporary glacial environment of the geomorphological consequences of glacier advance (of the Feegletscher Nord, Switzerland) across a paraglacial rock avalanche deposit. The landform-sediment assemblage at Feegletscher includes a rock avalanche scar, pulverised bedrock on the opposite valley wall, a down-valley tongue of unaltered rock avalanche debris, and a small arcuate end moraine that encloses a zone of hummocky debris. The sedimentology of the end moraine and hummocky material is conditioned by rock avalanche debris and can be differentiated from glacial materials that have no component of rock avalanche debris, indicating that the contribution of glacially reworked rock avalanche debris may be recognisable in deglaciated terrain. Remarkably, much of the overridden rock avalanche debris that underlies the surface hummocky sediments has maintained its angularity and delicate brecciation features, despite glacial action of up to 40 years duration. Previous studies assumed that debris transport would be enhanced significantly during the initial stages of glacier advance across rock avalanche debris, but we suggest that the large openwork blocks that characterise the surface of such deposits limits the potential for glacial reworking because of its high shear strength and ability to transmit subglacial meltwater efficiently.

Keywords: glacial geomorphology; moraine; paraglacial; reworking; rock avalanche; sedimentology.

\section{Introduction}

There is growing recognition that glacial sediment budgets and the evolution of mountain landscapes are influenced by the enhanced operation of geomorphological processes associated with 
deglaciation (e.g. Benn, 1989; Evans, 1999; Ballantyne, 2002; Curry et al., 2006, 2009a; Burki et al., 2009; McColl, 2012). Such geomorphological activity is termed 'paraglacial' (Church and Ryder, 1972; Ballantyne, 2002; McColl, 2012). Reworking and redistribution of sediments associated with paraglacial activity add complexity to the sedimentological and geomorphological record and hence there is a need for detailed studies of paraglacial activity in contemporary deglaciating environments. Such studies are required in order to quantify correctly bedrock erosion by glaciers, the evaluation of which has typically ignored any component of glacially reworked paraglacial material (Hallet et al., 1996; Burki et al., 2009).

Rock slope failures, including rock avalanches, are common during and after deglaciation because of the debuttressing of valley walls following glacier thinning and recession. It has been suggested that glacial sediment transfer will be enhanced where a glacier advances across and reworks such rock slope failure debris (Ballantyne, 2002). Furthermore, a number of studies have suggested that moraines may be especially large where they have been built by a glacier that has advanced across and reworked paraglacial slope deposits (e.g. Matthews and Petch, 1982; Benn, 1989; Evans, 1999; Ballantyne, 2002; Burki et al., 2009). Nonetheless, Burki et al. (2009) envisaged situations where the reworking of paraglacial material may have been underestimated or indeed not recognised because of subsequent glacial reworking of the material. Hence, there is a need to evaluate the geomorphology and sedimentology of such polygenetic deposits so that sedimentary criteria can be developed to recognise the influence and relative importance of glacial and paraglacial processes in mountain landscape development (e.g. Curry et al., 2009a). Currently, the identification of diagnostic sedimentary signatures for paraglacially reworked deposits is in its infancy (Curry et al., 2009a).

Despite the potential significance of glacial reworking of paraglacially modified materials, Ballantyne (2002) noted that there have been no modern analogue studies of landform development by glacial reworking of paraglacial rock avalanche debris that can be used for comparison against suspected examples from deglaciated terrains (e.g. Matthews and Petch, 1982; Benn, 1989; Shakesby and Matthews, 1996; Ballantyne, 2002; Burki et al., 2009). This is probably a consequence of a general global trend of glacier recession meaning that opportunities to study moraine formation at modern glaciers are rare (Winkler and Nesje, 1999; Winkler and Matthews, 2010).

In this study, we assess the sedimentological and geomorphological consequences of a relatively recent (late twentieth-century) advance of the Feegletscher Nord, Switzerland, across a rock avalanche deposit thought to be associated with deglaciation. Critically, there is documentary information on glacier length change and rock avalanche occurrence at Feegletscher, and as such, the geomorphological history of the area is reasonably well constrained. We employ a range of techniques that have been used previously (e.g. Hewitt, 1999, 2009; Shulmeister et al., 2009) to identify the influence of glacial and rock avalanche processes in the landscape record (including geomorphological mapping, clast lithology, clast shape and roundness, and sediment particle size 
analyses). These techniques are used (a) to describe the landform-sediment assemblage produced by glacial reworking of paraglacial rock avalanche debris; and, (b) to assess the extent to which the sedimentology and geomorphology of the assumed paraglacial rock avalanche deposit has been altered by a glacier having advanced across it.

Our overarching hypothesis is that the glacier will have reworked the rock avalanche deposit significantly to produce a sediment-landform assemblage that is strongly conditioned by rock avalanche material. Shakesby and Matthews (1996) described landforms and sediments of Loch Lomond Stadial (Younger Dryas) age within Craig Cerrig-gleisad cirque, in the Brecon Beacons of south Wales, which they interpreted to be the product of glacial reworking of rock avalanche material. Notably, this included a raised area (up to $20 \mathrm{~m}$ above the surrounding valley floor) of sub-parallel ridges containing angular sediment with some evidence of glacial striations. This was interpreted to be glacially reworked landslide debris. In addition, Hewitt $(1999,2009)$ and Shulmeister et al. (2009) have suggested a range of sedimentological criteria by which to recognise the influence of rock avalanches in the landscape record. We adopt these criteria and previous descriptions to predict that moraines produced by glacial reworking of rock avalanche debris will (i) be composed of the same lithology as the parent rock wall, and will thus contain a limited range of lithologies compared to glacial sediments, probably with a single or dominant lithology; (ii) contain dominantly angular and very angular clasts; (iii) have a similar particle size distribution to unmodified rock avalanche material that is expected to be diamictic in nature but with a high proportion of fine-grained material due to crushing during rock avalanche emplacement; and (iv) contain some clasts with evidence of glacial wear (i.e. facets and striations), although will overall have fewer such features than purely glacial sediments. Additionally, several studies have indicated that the particle size distribution of rock avalanches is invariably self-similar, with fractal dimensions commonly exceeding 2.58 (e.g. Dunning, 2006; Crosta et al., 2007; Davies and McSaveney, 2009). By testing these predictions our study contributes to an understanding of how significant glacial reworking of paraglacial sediment might be in the formation of landforms, and to what extent these processes can be recognised in the landscape record.

\section{Study site}

This study describes the geomorphology of the proglacial zone of Feegletscher Nord (46 $06^{\prime} \mathrm{N}, 7^{\circ} 54^{\prime}$ E), Saaser valley, Switzerland (Figure 1). The proglacial zone is bounded by a $\sim 60$ to $120 \mathrm{~m}$-high Little Ice Age (LIA) moraine. Feegletscher Nord has receded by approximately $1100 \mathrm{~m}$ from its AD 1818 LIA maximum position (Bircher, 1982; SAS/VAW, 2009), although this general trend of recession has been punctuated by periods of advance. Feegletscher Nord receded rapidly by $520 \mathrm{~m}$ between 1953 and 1956 to a position similar to its current extent (SAS/VAW, 2009). It had already been experiencing recession from 1923 of between 2 and $60 \mathrm{ma}^{-1}$. The glacier then advanced at a rate of between 6 to $87 \mathrm{ma}^{-1}$ to a maximum position in 1988, marked in the proglacial zone by the end 
moraine marked ' $\mathrm{B}$ ' in Figure 1 (see also Figure 2a for 1985 terminus position, and Figure 3 for terminus positions since 1969). Many other Alpine glaciers advanced in the 1970 s and 1980s following climate cooling from the 1950s to late-1970s (e.g. Beniston et al., 1994). Since this time, Feegletscher has receded by around $800 \mathrm{~m}$ to its current position (Figure $2 \mathrm{c}, 2 \mathrm{~d}$ and 3 ). This latest phase of recession has followed a similar pattern to the 1923 to 1956 recession, with steady initial recession until 1997 at a rate of between 5 and $55 \mathrm{ma}^{-1}$, followed by periods of very rapid recession, most notably by $111 \mathrm{~m}$ in 1997-1998 and by $209 \mathrm{~m}$ in 2000-2001 (SAS/VAW, 2009). The main trunk of the glacier now appears to be separating progressively from the main ice field at a short icefall, and looks to be almost stagnant down-valley from the icefall.

Figure 1:

\section{Figure 2:}

The geomorphology of the proglacial area is strongly conditioned by paraglacial slope activity. Paraglacial reworking of the steep drift-mantled slopes of the LIA moraine has already been investigated by Curry et al. (2006, 2009b). The bedrock valley walls are also subject to regular minor rock falls. Of particular significance to this study is a large rockfall, named the 'Guglen' event, which was reported in local chronicles to have taken place on the 28th July 1954 and to have involved greater than $1 \times 10^{6} \mathrm{~m}^{3}$ of rock (Ruppen et al., 1988). The magnitude of the event dictates that it be classified as a 'rock avalanche' according to the scheme of Hsü (1975). The Guglen rock avalanche scar remains clearly visible on the valley wall (Figure 2). As shown in Figure 2a and Figure 3, the glacier overrode much of the rock avalanche deposit, as is reported by Whalley and Krinsley (1974, pp. 96-97), and a small proportion of the rock avalanche was left untouched by the glacier. This eastern end of the rock avalanche run-out is labelled ' $A$ ' on Figure 1. Figure $2 a$ also shows that, before overriding by the glacier, the surface of the rock avalanche deposit comprised an openwork mass of large (metre-scale) blocks. Recent descriptions of rock avalanche deposits refer to this as a 'carapace facies' (e.g. Dunning, 2006; Hewitt, 2009). Some of the rock avalanche material was also deposited on the glacier surface (Whalley, 1979; Schnyder, Pers. Comm., 2010; Figure 2b).

Figure 3:

Consideration of the bedrock geology is pertinent to this study and it can be split into three lithological suites (Figure 5) based on the mapping of Bearth $(1964,1968)$. Bedrock outcrops in a number of locations in the proglacial area where surficial sediment is thin or absent (Figure 1). Most of the catchment is underlain by Palaeozoic mica-schist, and this lithology dominates the northern side of the valley. Weathering of the schist gives it a distinctive red colour, and the rock is known locally as 
Mischabel Crystal (Bearth, 1968). Much of the southern down-valley bedrock outcrops are Mesozoic metasedimentary rocks composed mainly of quartzite. The southern up-valley area is underlain by an ophiolite sequence comprising serpentinite, amphibolite and albite-schist.

\section{Methodology}

Geomorphological mapping was achieved through a combination of aerial photograph interpretation and field mapping following standard techniques (e.g. Hubbard and Glasser, 2005).

Samples of 50 clasts were analysed for clast shape (by measurement of orthogonal a-, b- and c-axes) and roundness using the Powers (1953) roundness scale, following techniques described by Benn (2004), as well as for lithology. Clast shape measurements were used to derive $C_{40}$ values for each sample (i.e. the proportion of clasts with a c:a axial ratio less than or equal to 0.4 ). For each clast sample, the proportion of angular and very angular clasts was combined to give a value for relative angularity (RA). Clast impact structures, such as brecciation, are often highlighted as evidence for pulverisation of rock during rock avalanches (e.g. Hewitt, 1999, 2009), and so were described and documented where they occurred.

Sediment particle size analysis has been described as unreliable for distinguishing between rock avalanche and glacial deposits by some (e.g. Hewitt, 1999), but others have described it as one of the most promising diagnostic characteristics of rock avalanche deposits (Shulmeister et al., 2009). We employ the technique here to assess its merits in differentiating between deposits of different origins at Feegletscher, and to assess the degree of modification of rock avalanche deposits by glacial processes. Sediment samples were taken from the different geomorphic units (labelled $A$ to $G$ in Figure 1) and analysed for particle size by dry sieving from -4 to $0 \Phi$, and by laser granulometry from $0 \Phi$ to $10 \Phi$. Sediment description was assisted by the use of the GRADISTAT package (Blott and Pye, 2001).

Rock avalanches commonly produce self-similar, or fractal, particle size distributions (e.g. Shulmeister et al., 2009; Dunning, 2006; Crosta et al., 2007; McSaveney and Davies, 2007) because the intergrain crushing involved in deposit emplacement generates an excess of fines. Self-similar (fractal) distributions have the form:

Where $N_{d}$ is the number of particles of size $d, N_{0}$ is the number of particles of reference diameter $d_{0}$, and $m$ is the fractal dimension given by the negative slope of a best fit line plotted on a double logarithmic plot of mean particle diameter (abscissa) against number of particles (ordinate). Grain size 
distributions with a fractal dimension of 2.58 or greater are regarded as self-similar (Sammis et al., 1987; Hooke and Iverson, 1995), although this technique has been criticised for being insensitive to multiple modes that may make up particle size distributions (Benn and Gemmell, 2002) and insufficient for discriminating between glacial sediments of different origins (Hubbard et al., 1996; Khatwa et al., 1999). We use this technique to assess whether it can be usefully employed to differentiate between glacial, rock avalanche and glacially modified rock avalanche deposits.

\section{Results}

\subsection{Geomorphology}

Figure 1 presents an overview of the geomorphology of the Feegletscher Nord valley. We focus here on the geomorphology related to the Guglen rock avalanche and the mid- to late-twentieth century cycles of glacier recession and advance. Active paraglacial debris flows and slope modification have already been described elsewhere (Curry et al., 2006, 2009b) but are also mapped on Figure 1.

Point ' $A$ ' on Figure 1 marks the easternmost extent of the Guglen rock avalanche deposit. Figures $2 \mathrm{a}$ and 3 demonstrate that this material, which is concentrated in the middle of the valley cross-section, was not overridden by Feegletscher during its late twentieth-century advance. This deposit is composed mainly of large (up to $6.5 \mathrm{~m}$ in diameter) angular boulders of red-coloured mica-schist. Many of the boulders exhibit brecciation features (Figure 4a) consistent with the material having been pulverised during transport and emplacement.

Point B on Figure 1 represents an arcuate cross-valley end moraine, punctuated in places by proglacial streams, marking the easternmost extent of the glacier during 1988 after sustained advance from 1957. Together with lower valley hummocky deposits (marked as point 'C' on Figure 1) this end moraine is one of the landform-sediment units produced by glacial reworking of the Guglen rock avalanche deposit. Photographs from the 1970s indicate that end moraine sediments derived a significant proportion of material from supraglacial rock avalanche material (Figure 2b), although this material appears to have been partially overridden and bulldozed during the 1980s (Figure 2a). The northern and southern limbs of the end moraine are subdued with heights less than $2 \mathrm{~m}$. In the middle of the valley the end moraine is a smear of material over unaltered rock avalanche material (as at point ' $A$ ') and so rises up to $6 m$ above the valley floor.

\section{Figure 4:}


Inside the 1988 glacier limit, and extending 200m up-valley there is a zone of lower valley

232 hummocky deposits (point 'C' on Figure 1). This hummocky zone takes the form of a raised cone of

233 material emanating from an up-valley break of slope, beyond which is a small proglacial lake (Figure

$2342 \mathrm{~d}$ ) which has an area of approximately $5,700 \mathrm{~m}^{2}$ and formed in response to glacier retreat in 2000-

235 2002. Drainage from the proglacial lake is via a surface overspill channel in the region of the

236 intersection of the upper hummocky moraine and modern rockfall debris (points $F$ and $G$ respectively

237 on Figure 1) and via sub-surface flow pathways in the region of the upper hummocky moraine (point $F$

238 on Figure 1). Drainage via the surface overspill channel is episodic, taking place only at high lake

239 stage, whereas drainage via sub-surface pathways is continuous. The topography of the lower

240 hummocky zone, relative to the valley floor on either side, is greatest in the centre of the valley, and in

241 the down-valley direction. Its central axis parallels the valley axis, and it slopes down on either side

242 where it meets proglacial streams. Individual hummocks protrude up to $1 \mathrm{~m}$ in height and generally

243 have diameters of 1 to $3 \mathrm{~m}$. They are typically composed of a thin drape $(<0.5 \mathrm{~m})$ of grey-coloured

244 diamicton over metre-scale red mica-schist boulders. These underlying boulders are commonly

245 brecciated and angular (Figure 4b).

246

247 On the true right of the valley the mica-schist rock avalanche deposit meets the Mesozoic quartzite

248 bedrock on the valley side (Point ' $D$ ' on Figure 1). Figure 4c demonstrates that the contact between

249 the two is marked by pulverised local quartzite bedrock. This area would have been in the direct path

250 of the 1954 Guglen rock avalanche. The down-valley continuation of this bedrock outcrop does not

251 appear to have been affected by rock avalanche impact, and instead has been sculpted and

252 smoothed by glacial erosion.

253

254 Much of the true right valley side (from points $E$ to $G$ on Figure 1 ) and the true left of the valley is

255 covered by a mixture of rock avalanche material and diamicton either from direct glacial deposition or

256 from paraglacial reworking of surrounding moraine slopes. There are several large blocks of mica-

257 schist that display evidence of pulverisation (see Figure 4d), and these are commonly overlain by

258 paraglacial material washed down from moraine slopes above.

260 Hummocky topography is present around the proglacial lake (point 'F' on Figure 1), forming a large

261 proportion of the natural dam that encloses the lake. Hummocks here are more subdued than those at

262 point $\mathrm{C}$, having a typical amplitude of less than $0.5 \mathrm{~m}$ and diameter less than $2 \mathrm{~m}$. Occasionally the

263 hummocks are composed of a drape of diamicton over angular rockfall-derived boulders, but stream

264 cut sections reveal that this diamicton sheet is at least $1.75 \mathrm{~m}$ thick in places and much of the

265 hummocky topography appears to reflect changes in diamicton thickness. During periods of high lake

266 level, surface overspill causes sediment downslope to be washed away by stream activity. Here the

267 underlying material is revealed to be the same fractured, angular, blocky red mica-schist that is

268 present across much of the area down-valley from here.

269 
At point $\mathrm{G}$ on Figure 1 there is a large deposit of angular blocks of mica-schist forming a wall of material up to $\sim 15 \mathrm{~m}$ high at its highest point, sloping downward toward the lake outlet. Pulverised rocks with scalloped impact marks are common in this deposit. This material appears to emanate from the trail of rockfall debris descending from the northern valley wall beneath the Guglen rock avalanche scar and further to the west above the true left of the glacier. Were it not for the presence of the proglacial lake this would be a continuous cone of rockfall material extending from the valley wall to the rockfall deposit at point G. Photos of this area from 2000 to 2002 revealed that this deposit was likely emplaced by a rockfall event onto stagnating ice shortly before complete deglaciation of the area.

\subsection{Clast lithology}

Figure 5 presents the lithological composition of clast samples across the proglacial zone. Comparison is made here between rock avalanche material (points A and D on Figure 1), the 1988 end moraine (point $B$ on Figure 1), the lower valley hummocks (point $C$ on Figure 1), upper zone of hummocks, (point $F$ on Figure 1), modern rockfall (point $G$ on Figure 1), and the LIA moraine.

As expected, modern rockfall deposits (samples DC1 and G1) are composed of a single lithology (mica-schist). Likewise the easternmost extent of the Guglen rock avalanche (samples A1 and A2) deposit is composed solely of mica-schist reflecting its origin from a point source, as is sample E1 in the direct path of the Guglen rock avalanche.

The LIA moraine (samples LIA1 and LIA2) is dominated by mica-schist, but with a significant proportion (34\% and $22 \%$ respectively) of quartzite. Sediment within the upper zone of hummocky moraine (samples F1 to F6) has a more mixed lithological composition, with all three lithological suites represented, although mica-schist dominates and the proportion of ophiolite rocks (between 0 and $40 \%$ ) is higher than anywhere down-valley because of the close proximity to outcrops of ophiolite bedrock.

297

The lithological composition of the zone of lower valley hummocks and the 1988 end moraine is more complex. The northern limb of the end moraine (samples B1 and B2) is composed entirely of micaschist material, although no clast samples were analysed for lithology in the southern part of the end moraine. Although the underlying geology on this northern side of the valley is dominated by micaschist, the end moraine is conspicuously monolithologic compared to the neighbouring LIA moraine samples on the same limb of the valley (Figure 5), which contain significant quantities of quartzite, although also dominated by mica-schist. Within the arc of the southern part of the 1988 end moraine (samples C1, C2 and C3), the proportion of quartzite rock increases in the lower hummocky deposits (up to $50 \%$ of clasts). This likely reflects the proximity to the outcrop of quartzite on the true right of the valley, although quartzite underlies much of the lower valley proglacial zone. This pattern of schist- 
dominated sediments on the true left of the valley, with a decreasing schist component toward the true right can be seen elsewhere in the lower valley hummock sediments (samples C4 to C7).

\section{Figure 5:}

\subsection{Clast shape and roundness}

Figure 6 presents clast shape $\left(\mathrm{C}_{40}\right)$ and relative angularity $(\mathrm{RA})$ data from six different sediment types. Table 1 presents summary descriptive statistics for the RA, $\mathrm{C}_{40}$ and proportion of faceted clasts for each of these six sediment types. Striations were not observed.

\section{Figure 6:}

\section{Table 1:}

The modern rockfall and Guglen rock avalanche debris both have similar characteristics, with high angularity ( $89 \%$ and $95.5 \%$ respectively) and high $\mathrm{C}_{40}$ values (73\% and $81.5 \%$ respectively) representing a dominance of slabby and elongate clast shapes (Figure 6 and Table 1).

Figure 6 and Table 1 demonstrate that the glacially reworked rock avalanche sediments of the lower valley hummocky zone and the 1988 end moraine can both be differentiated from other sediment types based on clast angularity and shape characteristics. The lower valley hummocks and end moraine sediments contain almost double the proportion of angular clasts (RA of $42.4 \%$ and $53.6 \%$ respectively) compared to the glacially derived sediments of the upper hummocks (RA of $25.0 \%$ ), and have a higher RA value than glacially transported clasts from the LIA moraine $(31.0 \%)$. The mean $C_{40}$ values of the lower valley hummocky deposits $(79.6 \%)$ and end moraine $(87.6 \%)$ are much higher than that of the upper valley glacial sediments $(50.8 \%)$, and a little higher than that of the LIA moraine $(70.0 \%)$. Lower valley hummocks and end moraine sediments are less angular than the Guglen rock avalanche material and modern rockfall, although $\mathrm{C}_{40}$ characteristics are similar, demonstrating dominantly slabby and elongate clast shapes.

The proportion of faceted clasts also allows discrimination between sediment types. Lower valley hummocky deposits and end moraine sediments have a lower proportion of faceted clasts $(32.8 \%$ and $14.0 \%$ respectively) than other glacially transported sediments (upper hummocky deposits $49.2 \%$ and LIA moraine $44.0 \%$ ). Rockfall-derived materials have no faceted clasts, as expected. 
349 Figure 7 and Table 2 present sediment particle size data for the six sediment types and reveal that the most significant particle size difference is between the 1988 end moraine and the LIA moraine. The end moraine has a greater proportion of coarse grain sizes (especially gravel to pebble, -1 to -4 $\Phi, 2$ to $16 \mathrm{~mm}$ ) and the LIA moraine, although still dominated by gravel, has a greater proportion of fine sand to coarse silt ( 5 to $3 \Phi, 31$ to $125 \mu \mathrm{m}$ ) than the end moraine. Indeed, the end moraine has the coarsest mean particle size (very fine gravel) of all sediment types analysed (Table 2). All other sediment particle size distributions (modern rockfall, Guglen rock avalanche material, upper and lower valley hummocks) are similar (Figure 7), with similar mean particle sizes and proportions of gravel, sand and mud (Table 2). All are dominated by gravel, but with a high proportion of sand and low proportion of mud, and all have a similar mean grain size (very coarse sand). With the exception of the upper hummocks (sandy gravel), all sediment types are classified as muddy sandy gravel.

Figure 7:

Table 2:

Analysis of the fractal dimension (Table 2) of the sediment types reveals that only the modern rockfall and LIA moraine sediments are fractal (i.e. have a mean fractal dimension greater than or equal to 2.58), reflecting the higher proportions of mud found in these samples. All samples of these sediments were fractal (minimum and maximum values given in Table 2), although only 2 samples per sediment type were analysed. The lower valley hummocks and the Guglen rock avalanche material have similar mean fractal dimensions (2.52 and 2.55 respectively), although slightly lower than the 2.58 threshold. The standard deviation of mean fractal dimension and the minimum and maximum fractal dimension values for both sediment types demonstrate that some samples were fractal and others were not. Sediment in the end moraine and upper valley hummocks have similarly low fractal dimensions (2.43 and 2.44 respectively) reflecting the very low proportions of mud within these sediments. None of the end moraine or upper valley hummocks samples had fractal dimensions greater than 2.51 .

\section{Discussion}

383 Here we describe the landforms-sediment assemblage produced by the advance of the Feegletscher Nord over a paraglacial rock avalanche deposit, and assess the extent to which the paraglacial rock avalanche deposit has been altered by the glacier having advanced across it. We highlight the 
implications for correctly identifying the contribution of paraglacial rock slope debris to the development of glacial landforms and sediments, and evaluate whether glacier advance across such deposits necessarily leads to enhanced glacial sediment fluxes as has been suggested previously (e.g. Ballantyne, 2002).

\subsection{Landform-sediment signature of a glacially reworked rock avalanche deposit}

Evidence for the 1954 Guglen rock avalanche itself is very clear, and includes a prominent rock avalanche scar (Figure 1 and Figure 2), unaltered rock avalanche material (point A on Figure 1, Figure 2), pulverised bedrock on the valley wall opposite the rock avalanche scar (point $D$ on Figure 1, Figure 4c), and largely unaltered angular and brecciated blocks of glacially overridden rock avalanche debris across much of the valley floor (Figure 4b). The main geomorphological imprint of glacially reworked rock avalanche material is the presence of a small arcuate end moraine behind which sits a raised area of hummocky topography emanating from close to the up-valley source of the rock avalanche (Figures 1 and 2d).

Sedimentological evidence is used commonly to identify the influence of glacial processes and rock avalanches in the formation of mountain landforms (e.g. Hewitt, 1999, 2009; Tovar et al., 2008; Shulmeister et al., 2009; Shugar and Clague, 2011; Reznichenko et al., 2012). We hypothesised that glacially modified rock avalanche sediments would possess characteristics that were conditioned strongly by the parent rock avalanche material, and would therefore be dominated by a single lithology, contain mostly angular debris, have a fine-grained particle size distribution that would be similar to the parent rock avalanche material, and display some evidence of glacial working (e.g. facets). We evaluate these predictions, considering that the 1988 end moraine and the lower valley hummocks have been conditioned to some extent by glacial reworking of the Guglen rock avalanche material.

\section{Overall, the 1988 end moraine has inherited many of the characteristics of the rock avalanche} material and fits with the predictions outlined above. Sediment within the moraine has followed a complex transport pathway. Part of the Guglen rock avalanche sediment was deposited onto the glacier surface and was then re-deposited at the glacier front as the glacier advanced (Figure 2b). The sediment was then transported a short distance by a combination of bulldozing at the glacier front and by overriding and entrainment into the basal traction zone (Figure 2a). Sediments within the end moraine (i) are monolithologic (Figure 5); (ii) are angular, with a mean relative angularity intermediate between glacially worked (i.e. the upper valley hummocks and LIA moraine) and rockfall-derived materials (Figure 6, Table 1); (iii) have a high $\mathrm{C}_{40}$ value similar to rockfall and Guglen rock avalanche material (Figure 6 and Table 1); (iv) contain few faceted clasts (Table 1); and (v) have a gravel-rich particle size distribution (Figure 7, Table 2). The gravel-rich particle size distribution was not predicted, but is at least very similar to that of the unmodified rock avalanche material. The particle 
size distribution of end moraine sediments is not fractal, although no clear relationship between sediment origin and fractal dimension has emerged from this analysis (Table 2).

The zone of hummocky deposits in the lower part of the valley (point $C$ on Figure 1) has also been conditioned by reworking of rock avalanche deposits, but to a lesser extent than the end moraine. The surface cover of diamicton here probably represents melt-out of a combination of relatively unmodified rock avalanche material from the glacier surface deposited as the glacier receded, and subglacially worked rock avalanche material as the glacier advanced across the rock slope debris. These sediments are distinct from glacial sediments that have been produced without the influence of the Guglen rock avalanche (i.e. the LIA moraine and upper hummocky zone). The surface sediments of the lower hummocks (i) are composed of a range of lithologies (Figure 5); (ii) contain clasts that are more angular than other glacial sediments unaffected by glacier flow across rock avalanche debris (i.e. the LIA moraine and upper valley hummocks), but less angular than the 1988 end moraine (Figure 6, Table 1); (iii) have a generally higher $\mathrm{C}_{40}$ value than other glacial sediments (Figure 6 , Table 1); (iv) contain a lower proportion of faceted clasts than glacially derived sediments, although double the proportion compared to end moraine sediments (Table 1); and (v) have a particle size distribution not dissimilar to other glacial sediments, although particle size is a poor discriminator of sediment types at Feegletscher (Figure 7, Table 2). The fractal dimension of 2.55 is slightly lower than the 2.58 threshold of truly fractal particle size distributions, although examination of Table 2 does not reveal any clear pattern between sediment origin and fractal dimension.

Our results indicate that glacial landforms produced by glacial reworking of rock avalanche debris possess a sedimentological character that is conditioned by rock slope material and is distinct from other glacial sediments produced with no influence from the rock avalanche. The end moraine is notably similar to unaltered rock avalanche material, whilst the lower hummocky diamicton has characteristics intermediate between unaltered rock avalanche material and other glacial sediments produced without the influence of rock avalanche debris (i.e. the upper valley hummocks and LIA moraine). Hence, we have demonstrated that it may be possible to identify the influence of paraglacial rock slope failures on glacial landform development from fully deglaciated terrain. This is aided where evidence for rock avalanching is clear, such as a rock avalanche scar, unaltered rock avalanche debris and pulverised bedrock.

To our knowledge, this is the only study that has examined the consequences of glacial reworking of paraglacial rock avalanche debris in a contemporary glacial environment, and so opportunity for comparison with results from other studies is limited. The most relevant comparable study from the palaeo-glacial record is that of Shakesby and Matthews (1996) who examined Loch Lomond Stadial deposits within Craig Cerrig-gleisad cirque, Wales. They interpreted the landform-sediment assemblage here to be the product of glacial reworking of rock avalanche material. As at

462 Feegletscher, the area furthest down-valley comprised a tongue-shaped hummocky deposit of 
angular clast-supported diamicton that was interpreted to be unmodified rock avalanche material. The landforms indicative of glacial reworking of rock avalanche material included an area of sub-parallel transverse ridges up to $20 \mathrm{~m}$ in amplitude, and a debris-free area between these ridges and the cirque headwall. The sub-parallel transverse ridges are perhaps the equivalent of the lower hummocky zone at Feegletscher. One of the most striking similarities is that Shakesby and Matthews (1996) found that $16-32 \%$ of clasts within the sub-parallel transverse ridges displayed striations, and at Feegletscher $14-33 \%$ of clasts within the lower valley hummocks displayed faceting. There is also a low (2 to $4 \mathrm{~m}$ high) ridge at Craig Cerrig-gleisad, which could be the equivalent of the 1988 end moraine at Feegletscher, although Shakesby and Matthews (1996) were unable to determine whether or not it was of glacial origin.

There are clear similarities between the landform-sediment assemblages of glacial reworking of paraglacial rock avalanche debris at Feegletscher and Craig Cerrig-gleisad. However, it would perhaps be premature to imply that these characteristics are diagnostic of such processes given the limited range of field studies that have been undertaken. The pursuit of a diagnostic landformsediment signature does, however, merit further research, especially if modern examples of active glacial reworking of rock avalanche debris can be investigated. We caution, however, that the geomorphology and sedimentology of these deposits may not be uniquely distinctive. For example, an end moraine enclosing a zone of hummocky material is a landform assemblage common to many deglaciated valleys, and can be produced without the influence of a rock avalanche. Likewise, it would not necessarily be possible to identify the influence of a rock avalanche within the drape of diamicton of the lower hummocky zone without detailed analysis of a range of other glacial landforms and sediments (such as the modern rockfall and LIA moraine). These polygenetic landforms can only be identified with reference to a range of end member materials. Furthermore, evidence for rock avalanche scars and unaltered rock avalanche debris, which would indicate the potential for rock avalanche debris to have been incorporated into moraines, may not survive extensive and long-lived glaciation. Bentley and Dugmore (1998), for example, found that most rock avalanche scars and all rock avalanche debris in northern Iceland had been removed during the last glaciation.

A further complication in diagnosing the role of rock avalanches in moraine building is that the criteria used to identify such influences are still under development. Hewitt $(1999,2009)$ and Shulmeister et al. (2009) have provided much-needed criteria for identifying rock avalanches in the landscape record. However, there are uncertainties about some of these criteria and how to interpret the evidence. In particular, particle size analysis has been deemed by Shulmeister et al. (2009) to be a very useful tool in identifying the influence of rock avalanches in moraine building, whereas Hewitt

498 (1999) suggested that particle size was a poor discriminator between rock avalanche deposits and glacial moraines. Hewitt et al. (2008) noted later, however, that for rock avalanche deposits the

500 proportion of sand is usually greater than the proportion of silt, and that, in contrast to glacial tills, the

501 proportion of clay is typically minor. Shulmeister et al. (2009) instead suggested that large rock 
avalanches should be dominated by fine-grained material as a consequence of crushing during emplacement, whereas smaller rockfalls would be matrix-free, and colluvial deposits would have a coarser matrix. The Guglen rock avalanche material and the glacially modified rock avalanche material both have only a very minor component of fine-grained material, particularly clay, and are instead dominated by gravel with a secondary component of sand. This is in agreement with the results of Hewitt et al. (2008). Most sediment facies are classed as muddy sandy gravel (Table 2), with the exception of the upper valley hummocks (sandy gravel). These descriptions are very similar to those obtained by Shugar and Clague (2011) for large rock avalanches emplaced on the Black

510 Rapids Glacier, Alaska. We note, however, that recent work by Reznichenko et al. (2012) indicates

511 that the fine fraction in rock avalanche debris may be under-estimated in traditional sieve and laser analyses of particle size distributions because clay-size particles adhere to larger particles even after

513 vigorous sieve shaking. We suggest also that eluviation of fine-grained material may have taken place 514 during re-working of rock avalanche material at Feegletscher, or that the rock avalanche was not of a sufficient magnitude to generate fine-grained particle size distributions through crushing.

516

\subsection{Extent of glacial reworking of rock avalanche debris}

518 Paraglacial sediments have been suggested to make a potentially significant contribution to glacial 519 sediment budgets (e.g. Hodgkins et al., 2003; Lukas et al., 2005; Porter et al., 2010) and to moraine 520 building (e.g. Matthews and Petch, 1982; Benn, 1989; Ballantyne, 2002; Burki et al., 2009), but as

521 Ballantyne (2002) noted, there have been no detailed studies of the effects of glacier advance across 522 debris generated through paraglacial rock slope failures. Based on a review of the limited existing 523 literature on this issue, Ballantyne (2002) suggested that debris transport would be significantly 524 enhanced during the initial stages of glacier advance across such debris accumulations. The relatively 525 modest geomorphological imprint of glacial reworking of paraglacial rock slope debris at Feegletscher 526 thus requires some explanation. In particular, much of the overridden rock avalanche deposit is 527 remarkably pristine, even at what would have been the ice-bed interface (i.e. below the surface cover 528 of diamicton in the lower hummocky zone). In the area overridden by Feegletscher, rock avalanche 529 boulders have retained their angularity, and delicate features, such as brecciation, have been 530 preserved (Figure 4b). This is a pervasive characteristic of overridden rock avalanche debris, despite 531 having experienced between $\sim 10$ to 40 years of occupation by active temperate glacier ice. We

532 suggest here that the extent to which paraglacial rock avalanche sediment will be reworked by a 533 glacier, and hence the extent to which glacial sediment flux will be enhanced during the initial stages 534 of glacial occupation, depends to a large extent on the sedimentary architecture of the rock avalanche 535 deposit.

537 Whilst studies of moraine formation at modern advancing temperate glaciers are rare, the available 538 evidence suggests that moraines are built by a range of processes including bulldozing of sediment 539 and boulders, dumping of supraglacial sediment, and melt-out from debris-rich basal ice and frozen540 on sediment (Winkler and Nesje, 1999; Winkler and Matthews, 2010). However, the conditions for 
541 moraine formation at Feegletscher during its advance differed from those described by Winkler and

542 Nesje (1999) and Winkler and Matthews (2010) for advancing Norwegian glaciers. Most notably, the

543 surface of the rock avalanche deposit at Feegletscher comprises openwork metre-scale boulders

544 (Figure 2a). This feature has been documented commonly for other rock avalanche deposits and is

545 typically referred to as a 'carapace facies' (e.g. Dunning, 2006; Hewitt et al., 2009). We suggest that

546 the apparent lack of reworking of the rock avalanche deposit is related to this carapace facies that

547 limits the effectiveness of a number of moraine-building glacial erosional processes.

548

549 Winkler and Nesje (1999) and Winkler and Matthews (2010) described moraine formation as a

550 consequence of bulldozing of sediment at some advancing Norwegian glaciers. They explained that

551 bulldozing is most effective in producing end moraines where the pre-existing sediment is water-

552 saturated and contains a high proportion of fine-grained material. Conversely, coarser and more

553 angular sediments have higher shear strength and thus require greater pressure to generate a

554 moraine. This latter condition is more similar to the situation at Feegletscher where the glacier was

555 unable to bulldoze significant quantities of the large blocks on the valley floor. Winkler and Nesje

556 (1999) and Winkler and Matthews (2010) also observed rotation and relocation of large boulders

557 ahead of advancing ice fronts, although the extent to which this process operated depended on

558 whether boulders were embedded in soft sediments, and on the shape and orientation of boulders in

559 relation to the ice front. We suggest that this process was relatively unimportant in moraine building or

560 sediment reworking at Feegletscher because tightly packed blocks in the carapace facies acted to

561 prevent removal of neighbouring blocks. Thus, the sedimentology of the surface of the rock avalanche

562 deposit acted as a form of rock armour.

563

564 Basal sediment entrainment through penetration of a winter cold wave (e.g. Weertman, 1961) would

565 have only a limited effect on block removal and transport because the size of many of the blocks is

566 likely to be greater than the depth of penetration of a cold wave into the bed. The temperate glacial

567 conditions at Feegletscher limit the operation of such processes. Likewise, temperate glaciers do not

568 typically possess thick debris-laden basal ice layers that could abrade or remove underlying blocks.

569 No basal ice was reported at Feegletscher by Whalley and Krinsley (1974), although the same

570 authors did note that small quantities of fine-grained material were temporarily frozen to the base of

571 Feegletscher in cavities in the lee of bed obstacles. Such materials could permit limited abrasion of

572 the underlying rock avalanche debris.

573

574 Glaciofluvial sediment evacuation is typically the most effective process of subglacial erosion and 575 sediment transfer beneath temperate glaciers (e.g. Hallet et al., 1996; Alley et al., 1997; Swift et al., 576 2002). We suggest, however, that this process too would be of more limited efficacy because the 577 openwork boulders of the carapace facies act as relatively efficient, low-pressure drainage pathways 578 for water to negotiate the rock avalanche deposit without significant alteration of the deposit itself.

579 This point is confirmed by the results of fluorescent dye tracing experiments conducted as part of a 
related study in the proglacial zone of Feegletscher. Repeat dye traces were conducted to confirm hydrological linkage between the proglacial lake (Figure 1) and the emergence of glacial waters from the rock avalanche deposit further down-valley (between the upper and lower hummocky zones Figure 1). Dye breakthrough curves show a time-to-peak from injection of between 62 and 76 minutes giving an average tracer transit velocity of $0.04-0.05 \mathrm{~ms}^{-1}$ (Figure 8). Previous tracer work focussing on alpine subglacial environments indicates that transit velocity figures in this range fall on the boundary between velocities associated with the switch from relatively inefficient distributed drainage networks to more efficient channelised networks (e.g. Nienow et al., 1998). The 'borderline' transit velocity measured here does not provide conclusive evidence about whether water flow through openwork boulders is efficient, or taking place via tortuous, spatially distributed pathways with an associated reduction in flow efficiency. Two factors indicate, however, that water is flowing in a relatively direct manner through the openwork matrix of the rockfall deposit. Firstly, the peaked nature of the breakthrough curves and the lack of subsidiary excursions in fluorescence after the main peak has passed indicates transit as a relatively discrete aliquot of dye and, therefore, transfer through a relatively discrete and efficient drainage pathway (e.g. Hubbard and Nienow, 1997; Figure 8). Secondly, analysis of dye breakthrough data obtained from Rieperbreen, Svalbard, by Gulley et al. (2012) indicated that the characteristics of dye breakthrough data normally associated with a switch from an inefficient distributed pathway to an efficient channelised system in subglacial environments (e.g. changes in transit velocity), may owe more to changes in the hydraulic roughness of the drainage pathway than to system morphology. Although our dye tracing experiments are conducted in a different geomorphological setting, in conjunction with the smooth and peaked breakthrough curve shape, we suggest that when the glacier occupied the rockfall deposit water was lost from the ice-bed interface into the relatively efficient drainage pathways within the rock avalanche debris. This would likely promote the preservation of delicate brecciation features and angularity across much of the deposit.

\section{Figure 8}

Our research represents a case study demonstrating that glacial overriding of a paraglacial rock avalanche deposit should not necessarily be expected to enhance glacial sediment flux greatly during the initial stages of glacier occupation. We note that the Feegletscher occupied the area of rock avalanche debris for a few decades and that given sufficient time, much or all of the debris could be removed or modified by glacial action. However, in light of recent advances in understanding of the sedimentology of rock avalanche deposits (e.g. Hewitt, 1999; 2009; Dunning, 2006) it is reasonable to suggest that the openwork carapace facies that comprises the surface of rock avalanche deposits may act as a key control in dampening glacier erosion rates and sediment fluxes where paraglacial rock slope debris is overridden. 


\section{Conclusion}

622 We have described the geomorphological and sedimentological consequences of late twentiethcentury glacier advance across an area of paraglacial rock avalanche debris at Feegletscher Nord,

624 Switzerland. To our knowledge, this is the only study from a modern glacial environment that has

625 examined glacial modification of paraglacial rock slope deposits. Description of the sediments and

626 landforms associated with glacial modification of paraglacial rock avalanche debris should aid in 627 identifying the contribution of paraglacial slope material to the generation of glacial landforms such as 628 moraines, and in assessment of glacial sediment budgets, which have typically ignored any 629 paraglacial input.

630

631 The landform-sediment assemblage produced by this sequence of events includes a prominent rock 632 avalanche scar on the valley wall, pulverised bedrock on the opposite valley wall, a small tongue of 633 rock avalanche debris untouched by glacial action at the area furthest down-valley, a small (up to $2 \mathrm{~m}$ 634 high) arcuate end moraine, and a zone of hummocky material within the end moraine that comprises 635 a thin drape of glacial diamicton over largely unaltered rock avalanche debris. The end moraine and 636 lower valley hummocky deposits represent landforms produced by glacial reworking of rock 637 avalanche material. End moraine sedimentology is strongly conditioned by the rock avalanche 638 material and is characterised by a single lithology, angular clasts, high $\mathrm{C}_{40}$ values, a gravel-dominated 639 particle size distribution similar to that of unmodified rock avalanche debris, and only limited evidence 640 for glacial working of clasts (i.e. faceting). The surface drape of diamicton of the lower valley 641 hummocky deposits is less strongly conditioned by the paraglacial rock avalanche material than the 642 end moraine sediment, with other rock types present and more evidence of glacially produced facets. 643 However, clasts within these sediments are generally more angular and with fewer facets than other 644 glacial sediments unaffected by the rock avalanche (i.e. from a LIA moraine and hummocky moraine 645 in the upper part of the Feegletscher valley). Whilst many of these geomorphological and 646 sedimentological characteristics are not unique to glacial reworking of paraglacial rock avalanche 647 debris, they are distinct from purely glacial sediments and pure rockfall debris. Hence the correct 648 identification of these polygenetic landforms in the landscape record requires reference to description 649 of other end member sediment types.

650

651 One of the most unusual characteristics of this landscape is the pervasive occurrence of angular and 652 brecciated rock avalanche boulders that have been overridden by Feegletscher and occupied by 653 active temperate ice for up to 40 years. These boulders display a surprising lack of evidence for 654 glacial reworking. Previous studies have suggested that glacier advance across an area of rock slope 655 debris would lead to enhanced sediment transfer during the initial stages of advance and could 656 contribute significantly to moraine building (e.g. Matthews and Petch, 1982; Benn, 1989; Ballantyne, 657 2002) but our case study at Feegletscher demonstrates that this is not always the case. We suggest 
that the surface 'carapace facies' of openwork boulders, common to many rock avalanche deposits, has a high shear strength and allows subglacial meltwater to be diverted away from the ice-bed interface through relatively efficient sub-surface drainage pathways. Hence, the sedimentology of rock avalanches means that they are less conducive to glacial erosion by either bulldozing, freeze-on, or subglacial meltwater flow.

\section{Acknowledgements}

SJC would like to thank the British Society for Geomorphology for fieldwork funding. Much of the fieldwork, laboratory work, data analysis and writing of this research was undertaken whilst SJC was funded by a C3W (Climate Change Consortium for Wales) lectureship at Aberystwyth University. PRP acknowledges funding from the University of Hertfordshire. Anna Denham, Lucy Ketcher and Craig Williams provided invaluable field assistance. We thank Benedikt Schnyder, Mike Hambrey and Oliver Perrott for the photographs used in Figure $2 a, 2 b$ and $2 d$ respectively. Brian Whalley offered invaluable discussions and maps of the glacier and rockfall extent during the 1970s. We thank Martin Smart for providing dye tracing data.

\section{$\underline{\text { References }}$}

Alley, R.B., Cuffey, K.M., Evenson, E.B., Strasser, J.C., Lawson, D.E., Larson, G.J., 1997. How glaciers entrain and transport basal sediment: physical constraints. Quaternary Science Reviews 16, 1017-1038.

Ballantyne, C.K., 2002. Paraglacial geomorphology. Quaternary Science Reviews 21,1935-2017.

Bearth, P., 1964. Geologischer Atlas der Schweiz 1:25 000, Blatt Nr. 43 Randa. - Schweiz. geol. Komm., Basel.

Bearth, P., 1968. Saas-Fee Geologischer Führer. Verkehrsverein, Saas-Fee.

Beniston, M., Rebetez, M., Giorgi, F., Marinucci, M.R., 1994. An analysis of regional climate change in Switzerland. Theoretical and Applied Climatology 49, 135-159.

Benn, D.I., 1989. Debris transport by Loch Lomond readvance glaciers in northern Scotland - basin form and the within-valley asymmetry of lateral moraines. Journal of Quaternary Science 4, 243-254.

Benn, D.I., 2004. Clast morphology. In: Evans, D.J.A. and Benn, D.I. (Eds.) A practical guide to the study of glacial sediments. Arnold, London. 
Benn, D.I., Gemmell, A.M.D., 2002. Fractal dimensions of diamictic particle-size distributions:

Simulations and evaluation. Geological Society of America Bulletin 114, 528-532.

Bentley, M.J., Dugmore, A.J., 1998. Landslides and the rate of glacial trough formation in Iceland. Quaternary Proceedings 6, 11-15.

Bircher W., 1982. Zur Gletscher- und Klimageschichte des Saastales. Glazialmorphologische und dendroklimatologische Untersuchungen. Phyische Geographie, 9, Geographisches Institut der Universität: Zürich.

Blott, S.J., Pye, K., 2001: GRADISTAT: A grain size distribution and statistics package for the analysis of unconsolidated sediments. Earth Surface Processes and Landforms 26, 1237-1248.

Burki, V., Larsen, E., Fredin, O., Nesje, A., 2009. Glacial remobilization cycles as revealed by lateral moraine sediment, Bodalsbreen glacier foreland, western Norway. Holocene 19, 415-426.

Church, M., Ryder, J.M., 1972. Paraglacial sedimentation - a consideration of fluvial processes conditioned by glaciation. Geological Society of America Bulletin 83, 3059-3072

Crosta, G.B., Frattini, P. , Fusi, N., 2007. Fragmentation in the Val Pola rock avalanche, Italian Alps. Journal of Geophysical Research-Earth Surface 112(F1).

Curry, A.M., Cleasby, V. \& Zukowskyj, P., 2006. Paraglacial response of steep, sediment-mantled slopes to post-'Little Ice Age' glacier recession in the central Swiss Alps. Journal of Quaternary Science 21, 211-225.

Curry, A. M., Porter, P. R., Irvine-Fynn, T. D. L., Rees, G., Sands, T. B., Puttick, J., 2009a.

Quantitative particle size, microtextural and outline shape analyses of glacigenic sediment reworked by paraglacial debris flows. Earth Surface Processes and Landforms 34, 48-62.

Curry, A. M., Sands, T.B., Porter, P. R., 2009b. Geotechnical controls on a steep lateral moraine undergoing paraglacial slope adjustment. Geological Society of London Special Publications 320, 181-197.

Davies, T.R., McSaveney, M.J., 2009. The role of rock fragmentation in the motion of large landslides. Engineering Geology 109, 67-79.

Dunning, S.A., 2006. The grain size distribution of rock-avalanche deposits in valley-confined settings. Italian Journal of Engineering Geology and Environment Special Issue, 117-121. 
736 Evans, D.J.A., 1999. Glacial debris transport and moraine deposition: a case study of the Jardalen 737 cirque complex, Sogn-og-Fjordane, western Norway. Zeitschrift Für Geomorphologie 43, 203-234.

Gulley, J.D., Walthard, P., Martin, J., Banwell, A.F., Benn, D.I., Catania, G., 2012. Conduit roughness and dye-trace breakthrough curves: why slow velocity and high dispersivity may not reflect flow in distributed systems. Journal of Glaciology 58, 915-925.

Hallet, B., Hunter, L., Bogen, J., 1996. Rates of erosion and sediment evacuation by glaciers: A review of field data and their implications. Global and Planetary Change 12, 213-235.

Hewitt, K., 1999. Quaternary moraines vs. catastrophic rock avalanches in the Karakoram Himalaya,

Hewitt, K., 2009. Catastrophic rock slope failures and late Quaternary developments in the Nanga Parbat-Haramosh Massif, Upper Indus basin, northern Pakistan. Quaternary Science Reviews 28, 1055-1069.

752

Hewitt, K., Clague, J., Orwin, J., 2008. Legacies of catastrophic rock slope failures in mountain landscapes. Earth Science Reviews 87, 1-38.

755

Hodgkins, R., Cooper, R., Wadham, J.,Tranter, M., 2003. Suspended sediment fluxes in a high--Arctic glacierised catchment: implications for fluvial sediment storage. Sedimentary Geology 162, 105-117.

Hooke, R.L., Iverson, N.R., 1995. Grain-size distribution in deforming subglacial tills - role of grain fracture. Geology 23, 57-60.

Hsü, K.J., 1975. Catastrophic debris streams (Sturzstroms) generated by rockfalls. Geological Society of America Bulletin 86, 129-140.

Hubbard, B., Nienow, P., 1997. Alpine subglacial hydrology. Quaternary Science Reviews 16, 939766 955.

Hubbard, B.P., Glasser, N.F., 2005. Field techniques in glaciology and glacial geomorphology. Wiley, Chichester. 
Khatwa, A., Hart, J.K., Payne, A.J., 1999. Grain textural analysis across a range of glacial facies. Annals of Glaciology 28, 111-117.

Lukas, S., Nicholson, L.I., Ross, F.H., Humlum, O., 2005. Formation, meltout processes and landscape alteration of High-Arctic ice--cored moraines - examples from Nordenskiöld Land, central Spitsbergen. Polar Geography 29, 157-187.

Matthews, J.A., Petch, J.R., 1982. Within-valley asymmetry and related problems of Neoglacial lateral-moraine development at certain Jotunheimen glaciers, Southern-Norway. Boreas 11, 225-247.

McColl, S.T., 2012. Paraglacial rock-slope stability. Geomorphology 153-4, 1-16.

McSaveney, M.J., Davies, T.R.H., 2007. Rockslides and their motion. In: Sassa, K., Fukuoka, H., Wang, F., Wang, G. (Eds.), Progress in Landslide Science. Springer, Heildelburg, pp. 113-133.

Nienow P., Sharp, M., Willis I., 1998. Seasonal changes in the morphology of the subglacial drainage system, Haut Glacier d'Arolla, Switzerland. Earth Surface Processes and Landforms 23, 825-843.

Porter, P.R., Vatne, G., Ng, F., Irvine-Fynn, T.D.L. 2010. Ice-marginal sediment delivery to the surface of a high-arctic glacier: Austre Broggerbreen, Svalbard. Geografiska Annaler: Series A, Physical Geography 92A , 437-449.

Powers, M.C., 1953. A new roundness scale for sedimentary particles. Journal of Sedimentary Petrology 23, 117-119.

Reznichenko, N.V., Davies, T.R.H., Shulmeister, J., Larsen, S.H., 2012. A new technique for identifying rock-avalanche-sourced sediment in moraines and some palaeoclimatic implications. Geology 40, 319-322.

Ruppen, P.J., Imseng, G., Imseng, W. 1988. Saaser Chronik. Verkehrsverein, Saas Fee.

Sammis, C., King, G., Biegel, R., 1987. The kinematics of gouge deformation. Pure and Applied Geophysics 125, 777-812.

SAS/VAW. 2009. The Swiss Glaciers, Yearbooks of the Glaciological Commision of the Swiss Academy of Science (SAS) published by the Laboratory of Hydraulics, Hydrology and Glaciology (VAW) of ETH Zürich. No. 1-124 (1881-2002). (http://glaziology.ethz.ch/swiss-glaciers/). 
812 Shakesby, R.A., Matthews, J.A., 1996. Glacial activity and paraglacial landsliding in the Devensian

813 Lateglacial: Evidence from Craig Cerrig-gleisiad and Fan Dringarth, Fforest Fawr (Brecon Beacons),

814 South Wales. Geological Journal 31, 143-157.

815

816 Shugar, D.H., Clague, J.J., 2011. The sedimentology and geomorphology of rock avalanche deposits

817 on glaciers. Sedimentology $58,1762-1783$.

818

819

820

Shulmeister, J., Davies, T.R., Evans, D.J.A., Hyatt, O.M., Tovar, D.S., 2009. Catastrophic landslides, glacier behaviour and moraine formation- a view from an active plate margin. Quaternary Science

822 Reviews 28,1085-1096.

824

Swift, D.A., Nienow, P.W., Spedding, N., Hoey, T.B., 2002. Geomorphic implications of subglacial drainage configuration: rates of basal sediment evacuation controlled by seasonal drainage system

826

827 evolution. Sedimentary Geology 149, 5-19.

Tovar, D.S., Shulmeister, J., Davies, T.R., 2008. Evidence for a landslide origin of New Zealand's

829

830

Waiho Loop Moraine. Nature Geosciences 1, 524-526.

831

Weertman, J., 1961. Mechanism for the formation of inner moraines found near the edge of cold ice caps and ice sheets. Journal of Glaciology 3, 965-978.

832

Whalley, W.B.,1979. The relationship of glacier ice and rock glacier at Grubengletscher, Kanton Wallis, Switzerland. Geografiska Annaler Series A, Physical Geography 61A, 49-61.

835

836

Whalley, W.B., Krinsley, D.H., 1974. Scanning electron-microscope study of surface textures of quartz grains from glacial environments. Sedimentology 21, 87-105.

838

839

Winkler, S., Nesje, A., 1999. Moraine formation at an advancing temperate glacier, Brigsdalsbreen, western Norway. Geografiska Annaler Series A, Physical Geography 81 A, 17-30. 
850 Figure 1: Proglacial geomorphology of Feegletscher Nord. Key sampled locations are marked $A$ to $G$.

$851 \quad A$ is unaltered rock avalanche material from the Guglen event; $B$ is the end moraine representing the advanced position of the glacier in 1988; $C$ is a zone of lower valley hummocky deposits in an area of glacially-overridden rock avalanche material; $D$ is a point of contact between the Guglen rock avalanche material and metasedimentary (quartzite) bedrock; $E$ is a zone of rock avalanche material from the Guglen event; $F$ is the upper zone of hummocky moraine composed of recently deposited (since $\sim 2000$ ) glacial sediment; $G$ is modern (since 2000 ) rockfall debris. 'LIA Moraine' refers to the Little Ice Age Moraine.

858

859

Figure 2: a) Feegletscher Nord in 1985 as it advanced over blocks from the Guglen rock avalanche, viewed approximately from the east facing west (Photograph by Benedikt Schnyder); b) Deposition of supraglacial rock avalanche debris in 1974, marked by black arrow (Photograph by Michael Hambrey); c) Feegletscher Nord in 2010 viewed from a similar position; d) Morphology of the glacially reworked rock avalanche debris (dark shaded area depicts unaltered rock avalanche debris; grey shaded are depicts reworked rock avalanche debris; black dotted line shows crest of lower valley hummocky zone; white dotted line shows Guglen rock avalanche scar).

Figure 3: Extent of the Guglen rock avalanche material (as it was in 1969) and the terminus position of Feegletscher Nord from 1969 to the present day, constructed from repeat aerial photography. Note that the rock avalanche material likely extended further up-valley (south west) beneath the mapped 1969 ice position.

Figure 4: Clast and bedrock impact structures of the Guglen rock avalanche deposit. a) Block of mica-schist at the contact between the unmodified rock avalanche material and the 1988 glacier limit.

877 Note the fracturing in the rock mass with a drape of glacial sediment on top of the disaggregated

878 boulder; b) Pulverised boulder of mica-schist in the hummocky zone (Point $C$ on Figure 1) up-valley 879 from the 1988 end moraine. Note the thin drape of grey-coloured diamicton on top; c) Pulverised 880 metasedimentary (mainly quartzite) bedrock (bottom left to centre) in contact with boulders of mica881 schist material from the Guglen event (bottom right to centre). Dotted white line shows approximate 882 contact between the two rock types. The position of this material is given as ' $D$ ' in Figure 1; $d$ ) Pulverised boulders on the true right valley side in the vicinity of point ' $E$ ' on Figure 1. 
886 Figure 5: Map of the bedrock geology of the lower Feegletscher valley and of the lithological

887 composition of sediment types found within the valley. Pie charts represent the proportions of clasts composed of the three principle rock suites in the area (i.e. mica-schist, quartzite and ophiolite).

889

890

Figure 6: Plot of the $\mathrm{C}_{40}$ index against relative angularity $(R A)$ for clasts from six different sediment

892 types found in the Feegletscher Nord valley.

893

894

895

Figure 7: Cumulative particle size distributions for sediment samples taken from the six different sediment types.

897

898

899

Figure 8: Example dye breakthrough curves showing mean tracer transit times of $0.05 \mathrm{~ms}^{-1}$ (solid line) and $0.04 \mathrm{~ms}^{-1}$ (dashed line) recorded in July 2010. Note the smooth peaked nature of both curves and the lack of any significant subsidiary peaks.

902

903

904

\section{List of Tables}

905

906 Table 1: Summary descriptive statistics for average $R A$ (relative angularity), $\mathrm{C}_{40}$ index, and proportion 907 of faceted clasts for six sediment types in the Feegletscher Nord valley. NB: Standard deviation could not be calculated for the $\mathrm{C}_{40}$ of the LIA moraine as only one sample of clast shape was measured.

911 Table 2: Summary particle size statistics for the six sediment types examined at Feegletscher Nord. 
Table 1: Summary descriptive statistics for average $R A$ (relative angularity), $\mathrm{C}_{40}$ index, and proportion of faceted clasts for six sediment types in the Feegletscher Nord valley. NB: Standard deviation could not be calculated for the $\mathrm{C}_{40}$ of the LIA moraine as only one sample of clast shape was measured.

\begin{tabular}{|l|l|l|l|}
\hline Sediment type & $\begin{array}{l}\text { Mean RA (\%) } \mathbf{R} \\
\text { standard deviation }\end{array}$ & $\begin{array}{l}\text { Mean } \mathbf{C}_{40}(\%) \pm \\
\text { standard deviation }\end{array}$ & $\begin{array}{l}\text { Mean proportion of } \\
\text { faceted clasts (\%) } \mathbf{~} \\
\text { standard deviation }\end{array}$ \\
\hline Modern rockfall & $89.0 \pm 4.2(\mathrm{n}=4)$ & $73.0 \pm 4.2$ & $0 \pm 0$ \\
\hline Guglen rock avalanche & $95.5 \pm 15.7(\mathrm{n}=4)$ & $81.5 \pm 10.9$ & $0 \pm 0$ \\
\hline LIA moraine & $31.0 \pm 1.4(\mathrm{n}=2)$ & $70.0 \pm N / A$ & $44.0 \pm 11.3$ \\
\hline Upper valley hummocks & $25.0 \pm 4.5(n=5)$ & $50.8 \pm 15.7$ & $49.2 \pm 15.0$ \\
\hline Lower valley hummocks & $42.4 \pm 22.6(n=5)$ & $79.6 \pm 10.5$ & $32.8 \pm 11.4$ \\
\hline End moraine & $53.6 \pm 24.3(n=5)$ & $87.6 \pm 6.1$ & $14 \pm 13.6$ \\
\hline
\end{tabular}


Table 2: Summary particle size statistics for the six sediment types examined at Feegletscher Nord.

\begin{tabular}{|c|c|c|c|c|c|c|c|}
\hline Sample & $\begin{array}{l}\text { Gravel / Sand / Mud } \\
(\%)\end{array}$ & Textural Group & $\begin{array}{l}\text { Mean Particle Size } \\
(\Phi)\end{array}$ & Sorting $(\Phi)$ & $\begin{array}{l}\text { Mean Fractal } \\
\text { Dimension } \pm \\
\text { Standard } \\
\text { Deviation }\end{array}$ & $\begin{array}{l}\text { Fractal } \\
\text { Dimension } \\
\text { Range } \\
\text { (Minimum - } \\
\text { Maximum) }\end{array}$ & Fractal? \\
\hline $\begin{array}{l}\text { Modern Rockfall } \\
(\mathrm{n}=2)\end{array}$ & $56.8 / 32.0 / 11.2$ & $\begin{array}{l}\text { Muddy sandy } \\
\text { gravel }\end{array}$ & $\begin{array}{l}-0.74 \\
\text { Very coarse sand }\end{array}$ & $\begin{array}{l}2.83 \\
\text { Very poorly sorted }\end{array}$ & $2.60 \pm 0.00$ & $2.60-2.61$ & Yes \\
\hline $\begin{array}{l}\text { Guglen Rock } \\
\text { Avalanche } \\
(n=10)\end{array}$ & $59.4 / 32.3 / 8.3$ & $\begin{array}{l}\text { Muddy sandy } \\
\text { gravel }\end{array}$ & $\begin{array}{l}-0.96 \\
\text { Very coarse sand }\end{array}$ & $\begin{array}{l}2.61 \\
\text { Very poorly sorted }\end{array}$ & $2.52 \pm 0.09$ & $2.41-2.68$ & No/Yes \\
\hline $\begin{array}{l}\text { LIA Moraine } \\
(n=2)\end{array}$ & $47.8 / 37.8 / 14.5$ & $\begin{array}{l}\text { Muddy sandy } \\
\text { gravel }\end{array}$ & $\begin{array}{l}-0.19 \\
\text { Very coarse sand }\end{array}$ & $\begin{array}{l}2.96 \\
\text { Very poorly sorted }\end{array}$ & $2.61 \pm 0.01$ & $2.60-2.62$ & Yes \\
\hline $\begin{array}{l}\text { Upper } \\
\text { hummocks } \\
(\mathrm{n}=3)\end{array}$ & $48.8 / 46.3 / 4.9$ & Sandy gravel & $\begin{array}{l}-0.62 \\
\text { Very coarse sand }\end{array}$ & $\begin{array}{l}2.51 \\
\text { Very poorly sorted }\end{array}$ & $2.44 \pm 0.10$ & $2.32-2.51$ & No \\
\hline $\begin{array}{l}\text { Lower } \\
\text { hummocks } \\
(\mathrm{n}=7)\end{array}$ & 49.4 / 41.0 / 9.6 & $\begin{array}{l}\text { Muddy sandy } \\
\text { gravel }\end{array}$ & $\begin{array}{l}-0.42 \\
\text { Very coarse sand }\end{array}$ & $\begin{array}{l}2.78 \\
\text { Very poorly sorted }\end{array}$ & $2.55 \pm 0.08$ & $2.45-2.64$ & No/Yes \\
\hline $\begin{array}{l}\text { End moraine } \\
(n=3)\end{array}$ & $69.5 / 24.2$ / 6.3 & $\begin{array}{l}\text { Muddy sandy } \\
\text { gravel }\end{array}$ & $\begin{array}{l}-1.59 \\
\text { Very fine gravel }\end{array}$ & $\begin{array}{l}2.31 \\
\text { Very poorly sorted }\end{array}$ & $2.43 \pm 0.06$ & $2.40-2.50$ & No \\
\hline
\end{tabular}




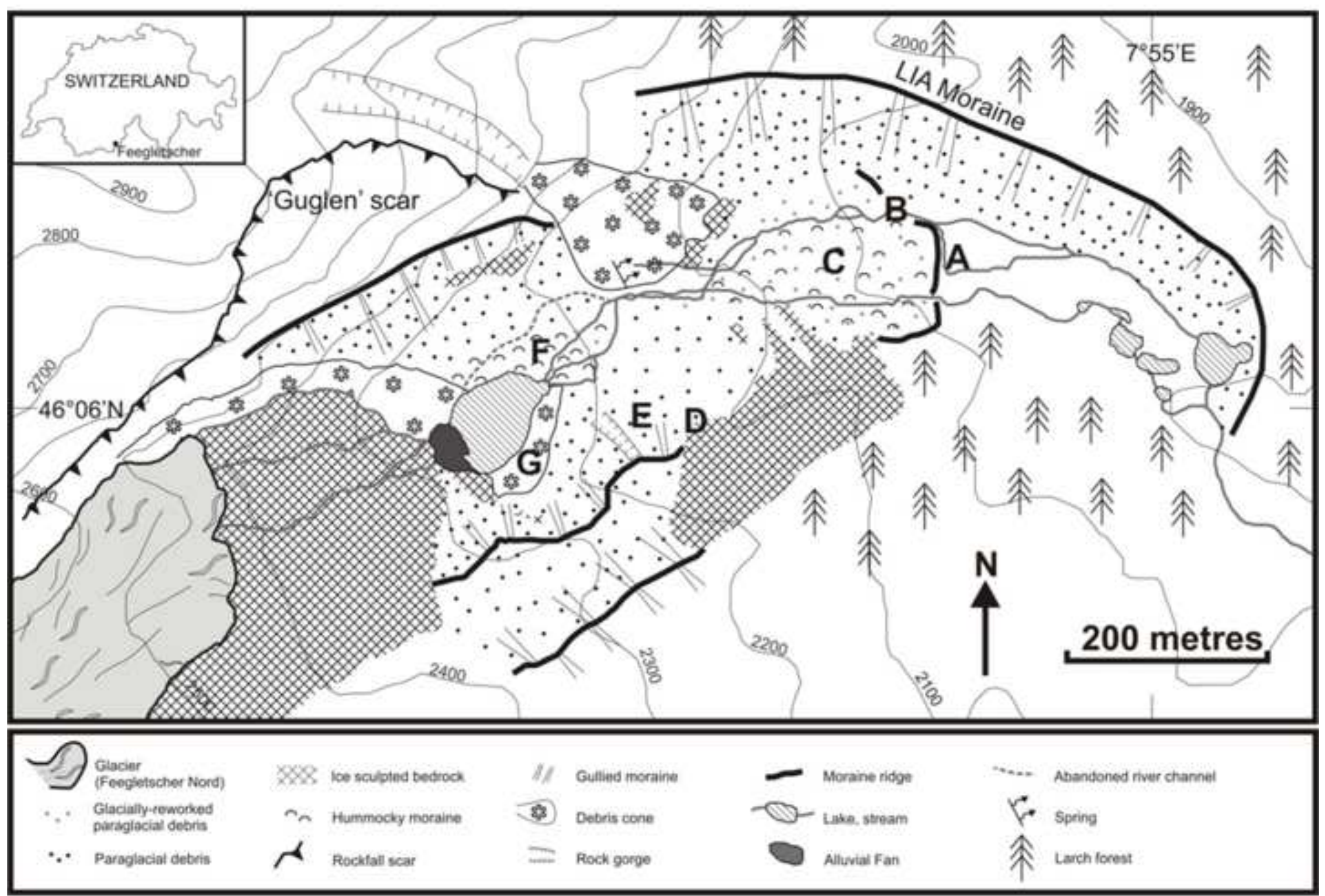


Click here to download high resolution image
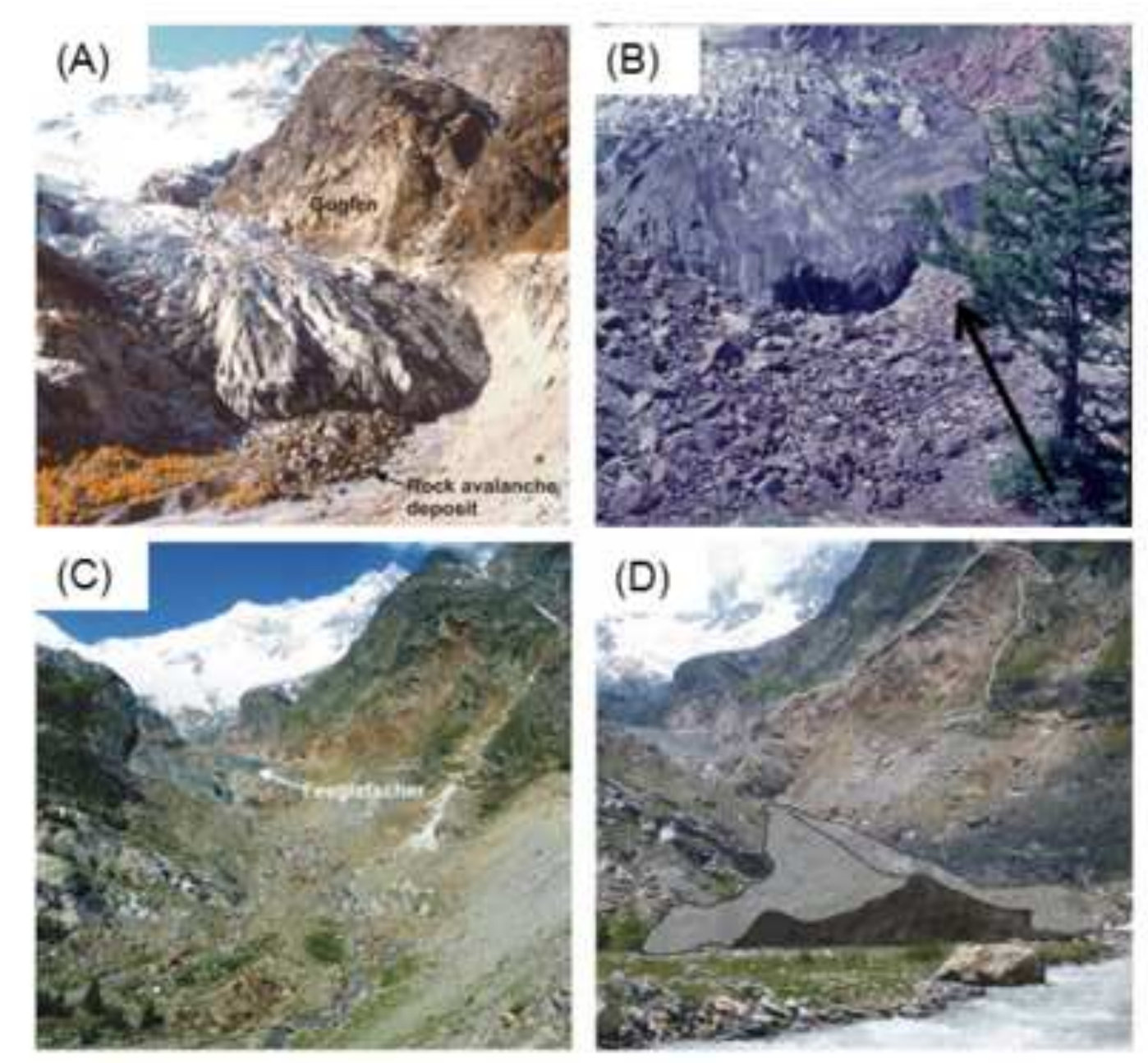

Figure 2 
Click here to download high resolution image

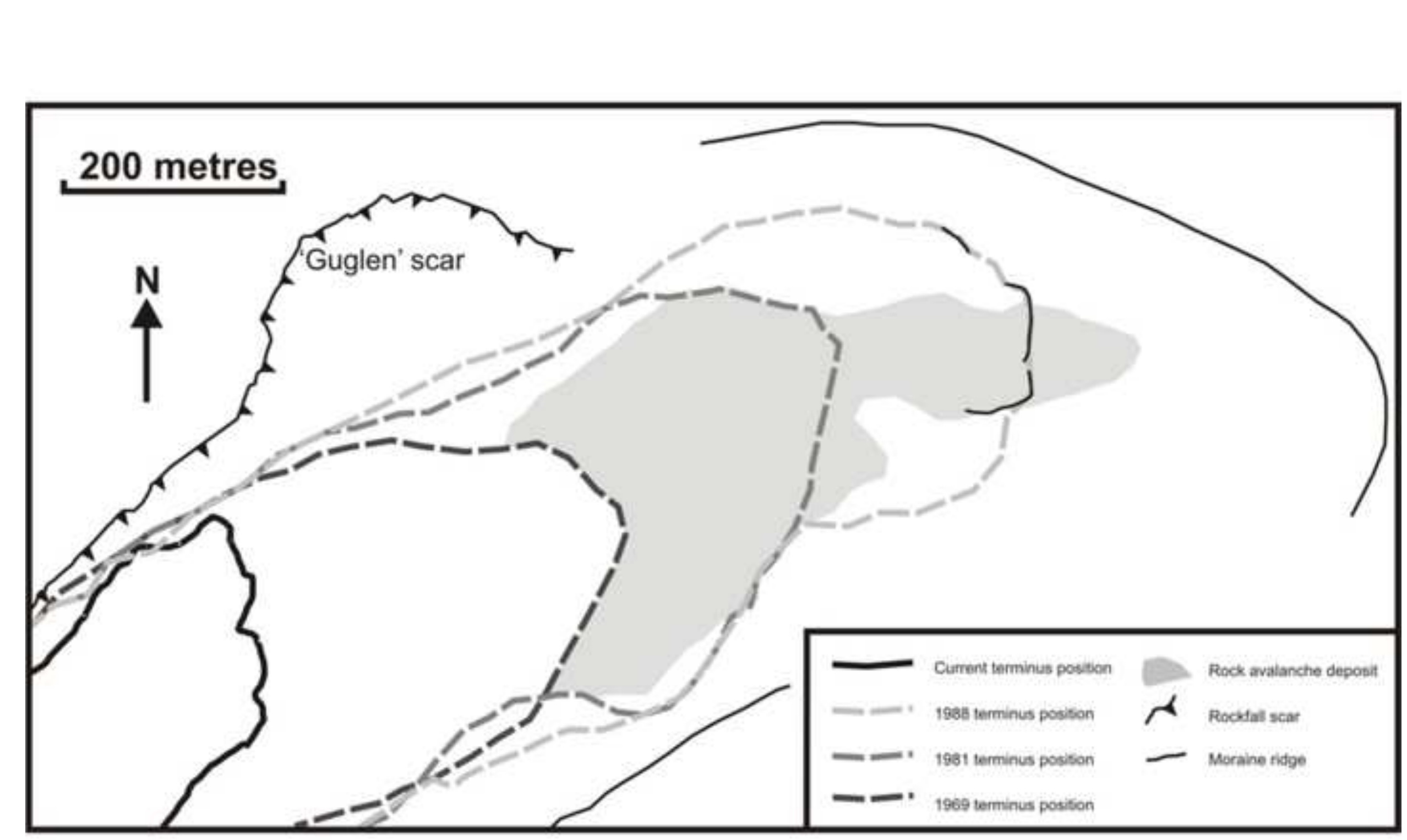

Cle here to download high resolution image 
Click here to download high resolution image
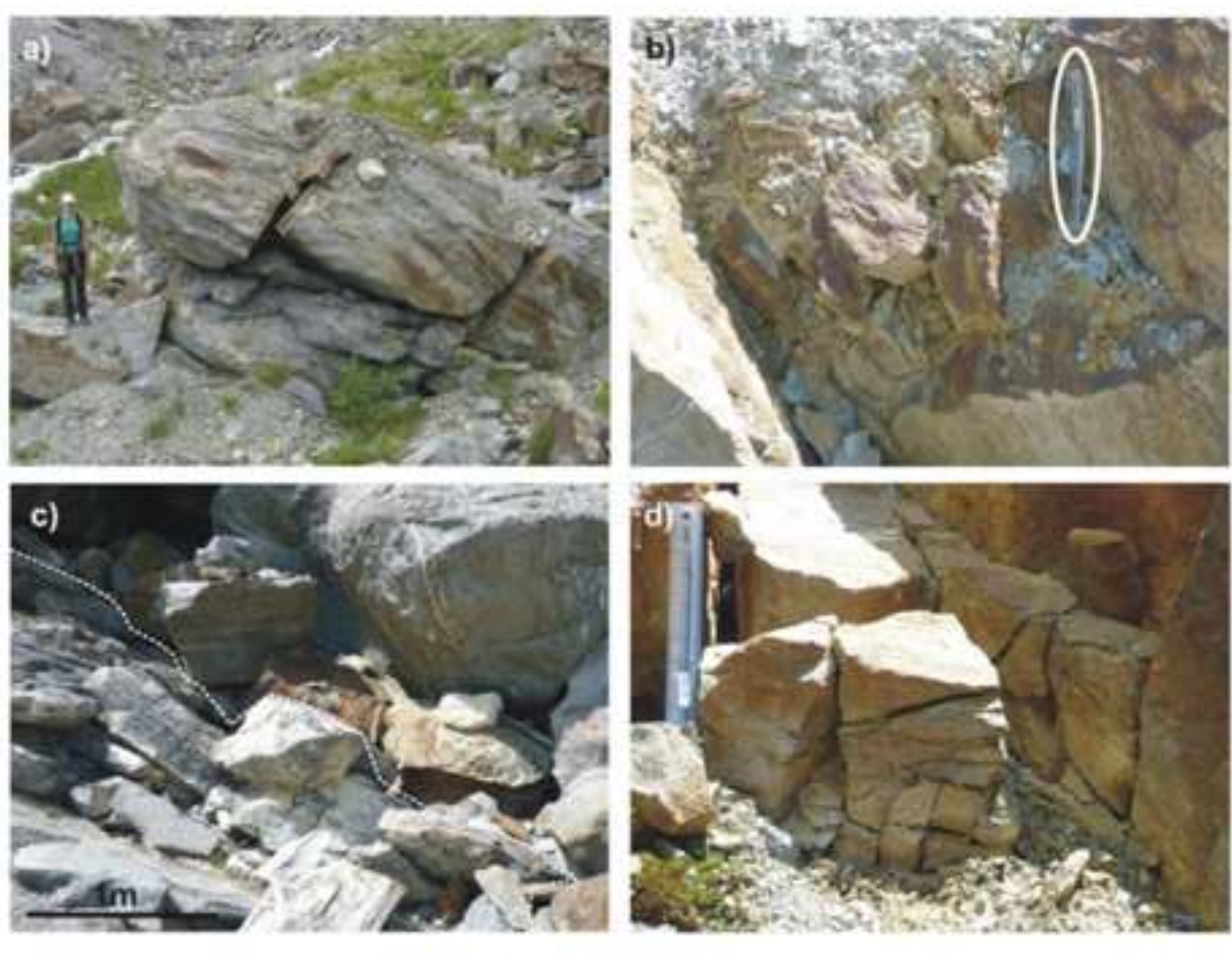

Figure 4

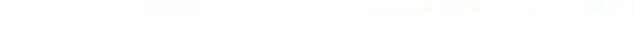

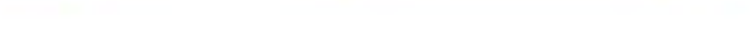

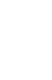

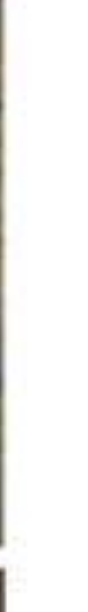

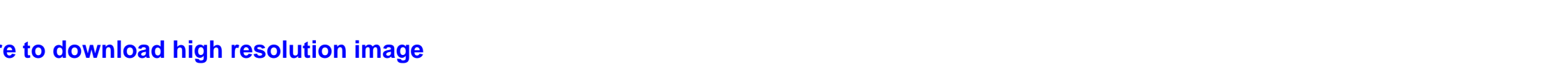

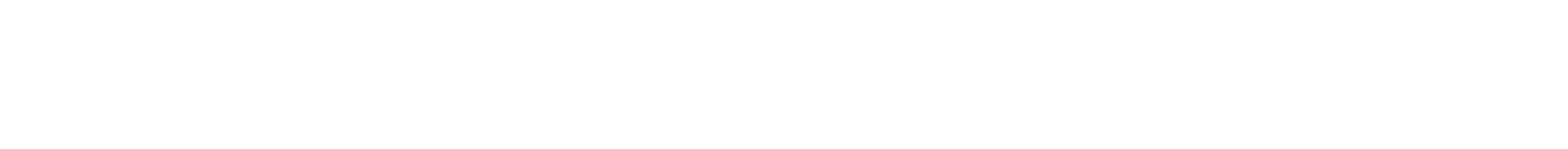

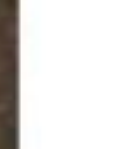$$
\text { . }
$$

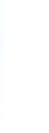




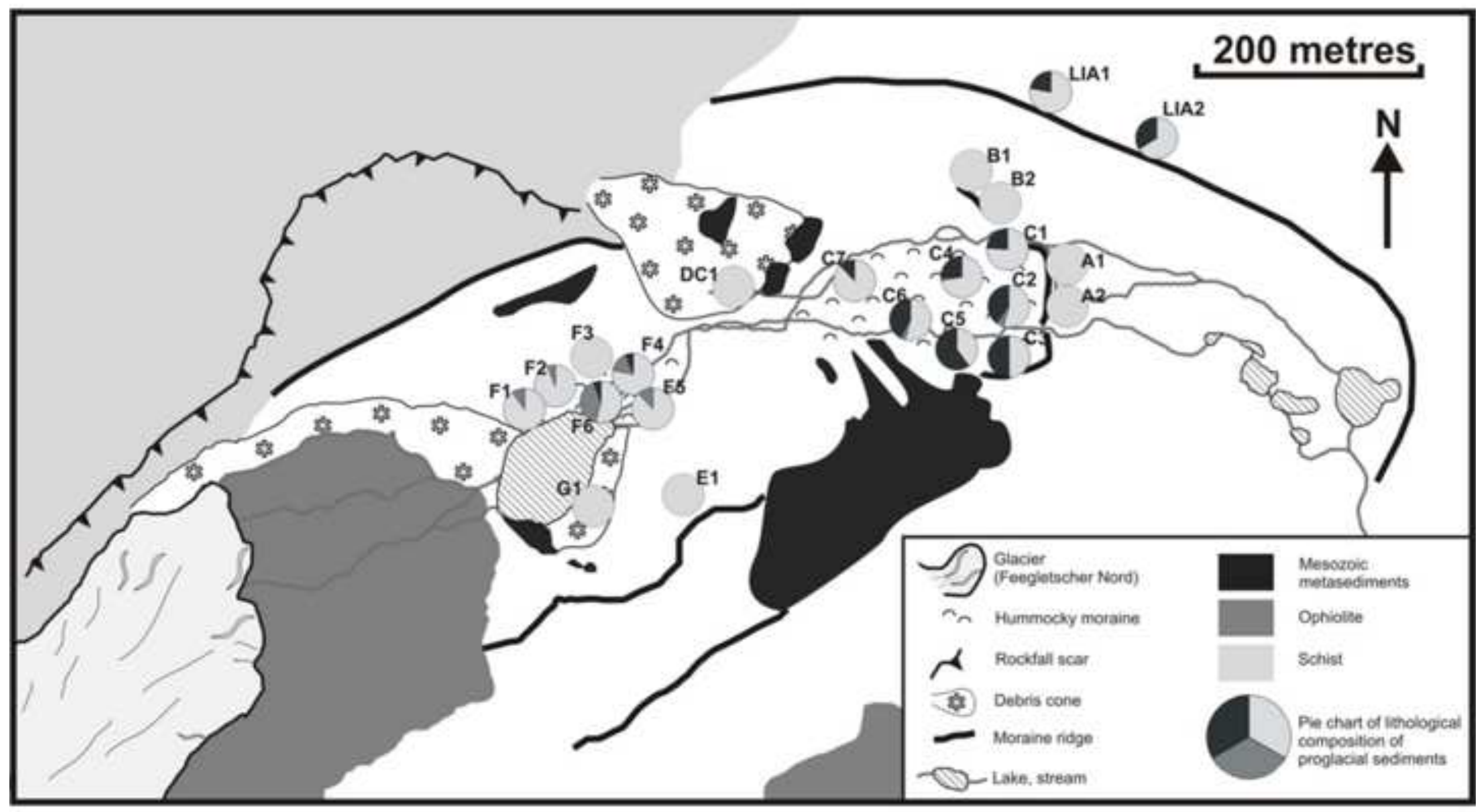


Click here to download high resolution image

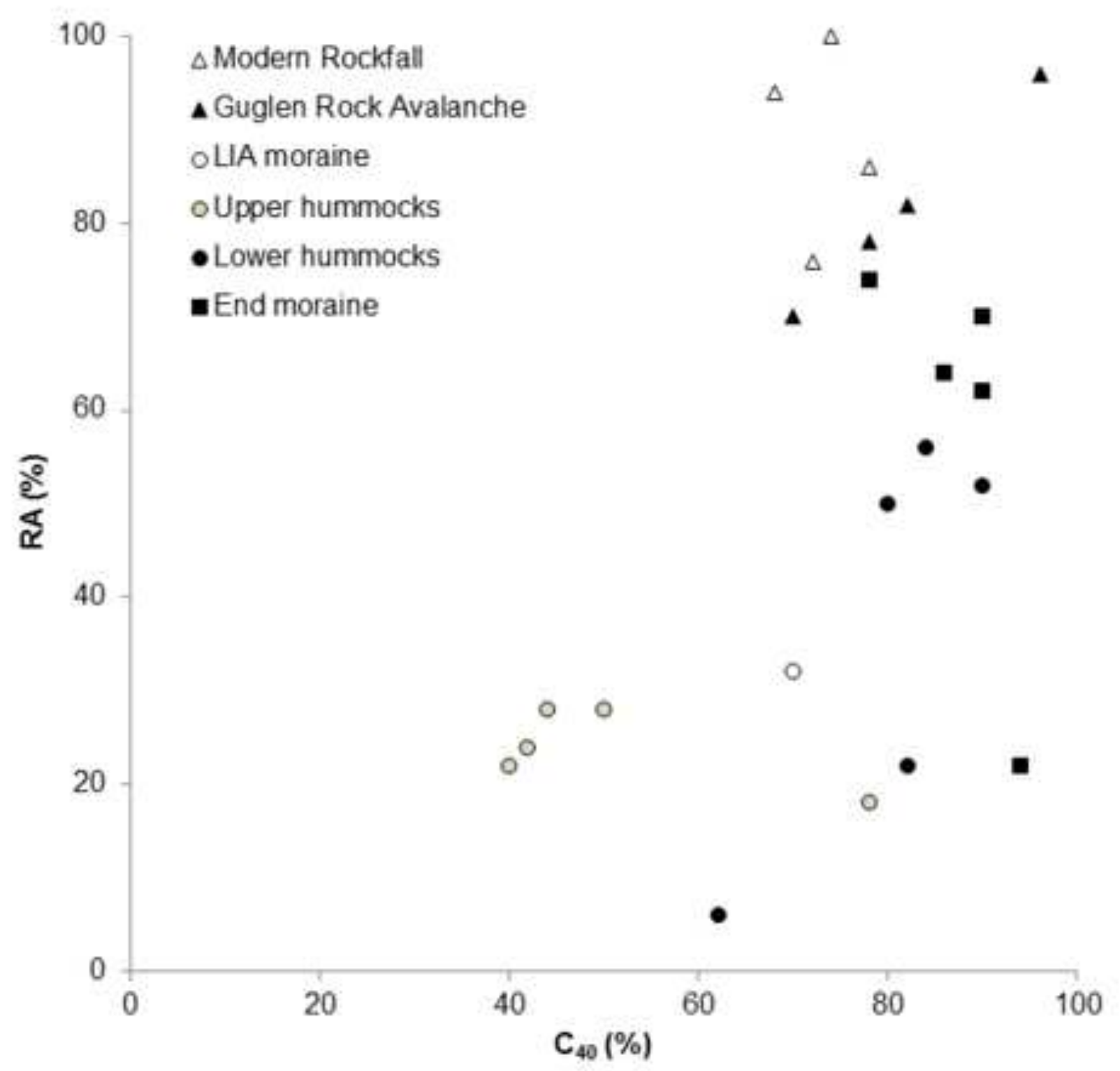


Click here to download high resolution image

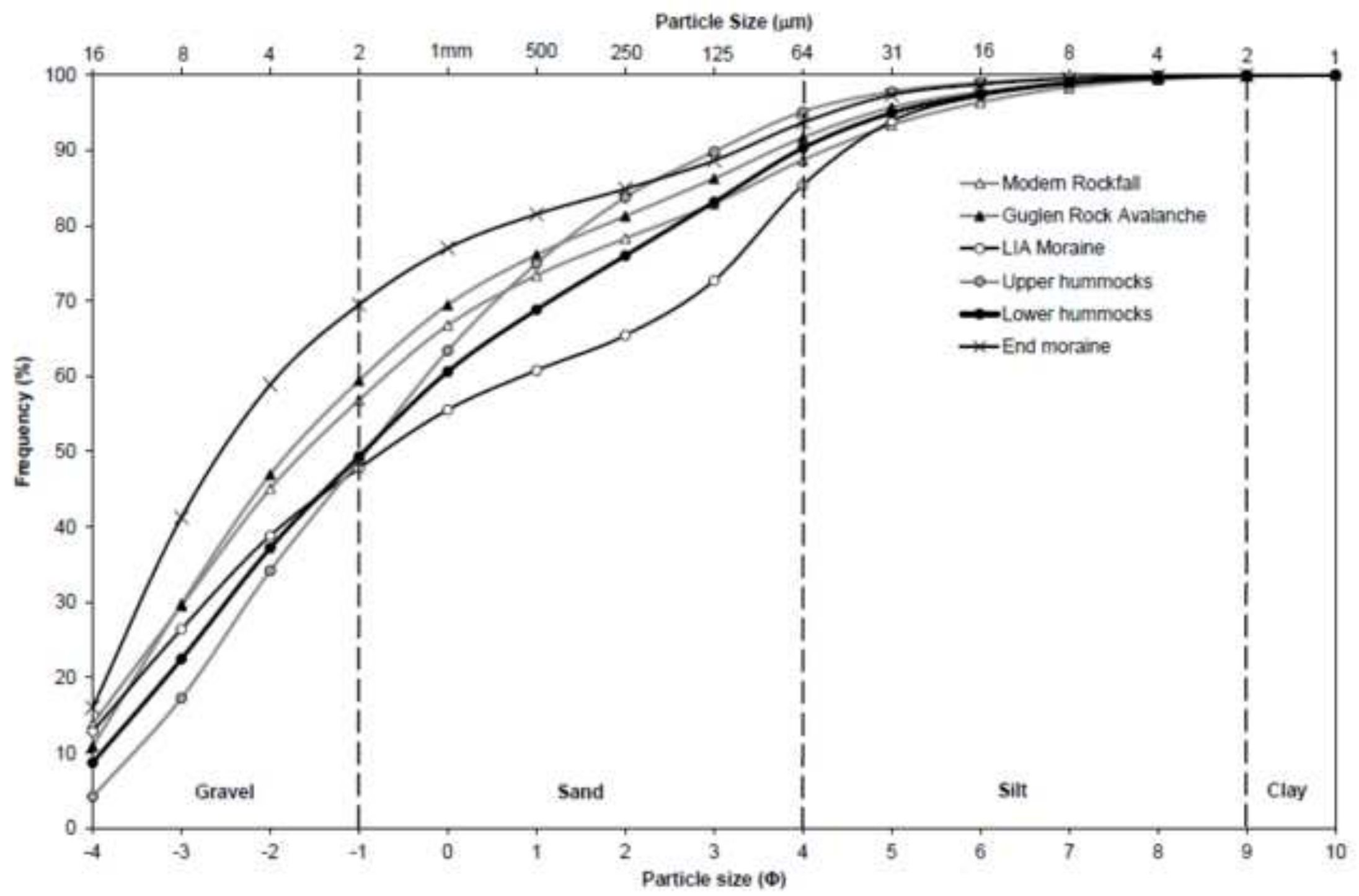




\section{Figure 8}

Click here to download high resolution image

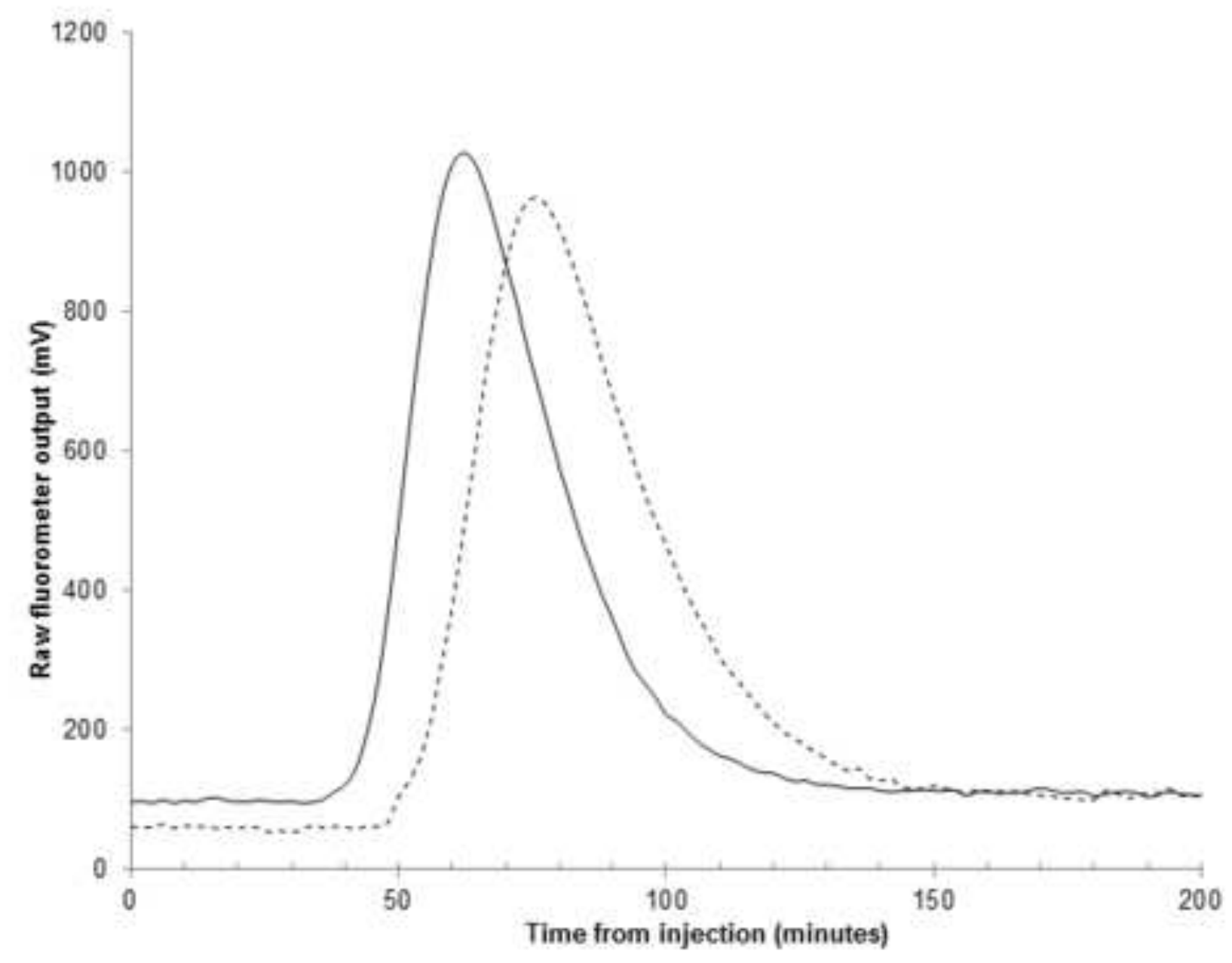

